\title{
Pengaruh Suplementasi Asam Amino Lisin, Metionin, Triptopan dalam Ransum Berbasis Lumpur Sawit Fermentasi terhadap Performans Produksi dan Kualitas Telur Ayam Ras
}

\author{
Yosi Fenita, Urip Santoso, Hardi Prakoso. \\ Jurusan Peternakan Fakultas Pertanian Universitas Bengkulu \\ Jalan W.R Supratman Kandang Limun Bengkulu
}

\begin{abstract}
The aim of this study was to evaluate the effect of feeding fermented palm oil sluge and critical amino acid (CAA); methyonine, lysine, and tryptophan supplementation on diet to performance and quality. The research design used was complety randomized design with 4 teatments; each treatment consists of P0; the control diet, without addition of critical amino acid. P1: the diet contains of $50 \%$ critical amino acid (Lys 113.26gr; Met 70.14gr; Trp 36.2gr), P2: 75\% critical amino acid (Lys 169.89gr; Met 105.21gr; Trp 63.35gr), and P3: $100 \%$ critical amino acid (Lys 226.52gr; Met 140.28gr; Trp 72.4gr) on diet.. The Parameter measured feed comsumption, feed conversi, egg weight, egg production, index yolk calours and income over feed cost of layer. The results showed that no significant $(P>0.01)$ to feed comsumption, feed conversio, egg weight, egg production but significant $(\mathrm{P}<0,05)$ index yolk calour. In conclutions, feeding fermented palm oil sludge with additionl of critical amino acid no effect to performance layer and to increase index yolk calour.
\end{abstract}

Key words: fermentation, of sludge of palm oil, critical amino acid.

\section{ABSTRAK}

Penelitian ini bertujuan untuk mengevaluasi pengaruh pemberian asam amino essensial (lisin, metionin, dan triptopan) dalam ransum berbasis lumpur sawit terhadap performans dan kualitas telur ayam petelur. Rancangan Percobaan yang digunakan adalah Rancangan Acak Lengkap, pada penelitian ini digunakan ayam petelur fase produksi umur 8 bulan sebanyak 40 ekor. Ayam petelur tersebut terbagi dalam 4 perlakuan yaitu perbedaan pemberian tingkat suplementasi asam amino essensial yaituP0 : tanpa suplementasi, suplementasi asam amino. P1: 50\% (Lys 113,26gr; Met 70,14gr; Trp 36,2gr), P2: suplementasi 75\% (Lys 169,89gr; Met 105,21gr; Trp 63,35gr), P3 : suplementasi 100\% (Lys 226,52gr; Met 140,28gr; Trp 72,4gr), suplementasi asam amino ini adalah dalam $100 \mathrm{~kg}$ bahan pakan. Variabel yang diamati adalah konsumsi ransum, konversi ransum, berat telur, produksi telur, warna yolk, dan income over feed cost. Hasil penelitian menunjukkan bahwa perlakuan pengaruh tidak nyata $(P>0,05)$ terhadap konsumsi ransum, konversi ransum, berat telur dan juga produksi telur, namun warna yolk nyata $(\mathrm{P}<0,05)$ dengan pemberian peningkatan asam amino kritis. Perlakuan dengan suplementasi asam amino essensial pada level $50 \%$ memberikan warna yolk yang nyata dampak terhadap kecerahan warna yolk dimana rataan warna yang didapat adalah 8,56. Jadi dapat disimpulkan bahwa suplementasi asam amino kritis dalam ransum berbasis lumpur sawit fermentasi pengaruh yang nyata terhadap warna yolk.

Kata kunci: fermentasi lumpur sawit, asam amino kritis.

\section{PENDAHULUAN}

Pakan merupakan salah satu faktor penting dalam usaha peternakan. Keterbatasan bahan pakan ternak menimbulkan usaha-usaha pemanfaatan limbah pertanian sebagai pakan ternak yang non-konvensional. Apalagi sampai saat ini pakan ternak unggas yang berasal dari biji-bijian pada dasarnya masih dikonsumsi oleh manusia, sehingga perlu diupayakan alternatif sumber bahan lain yang cukup potensial sebagai bahan pakan ternak.

Di alam ini banyak sekali tersedia sumber daya nabati maupun hewani yang dapat dimanfaatkan sebagai bahan 
pakan ternak yang tidak bersaing dengan kebutuhan manusia antara lain limbah pertanian maupun limbah industri. Sejalan dengan perkembangan industri tersebut, tentunya limbah yang dihasilkan juga terus meningkat. Jika penanganan limbah tersebut tidak tepat, maka akan menyebabkan terjadinya pencemaran lingkungan maupun pemborosan sumber daya. Salah satu jenis limbah yang dapat dimanfaatkan oleh ternak ayam adalah lumpur sawit. Lumpur sawit merupakan limbah dari proses pemerasan buah sawit untuk menghasilkan minyak sawit kasar atau crude palm oil (CPO) yang diperoleh dengan cara mensentrifusi limbah cairan dengan menggunakan alat yang disebut decanter (Sinurat, 2003). Penggunaan lumpur sawit dalam ransum ternak harus melalui penanganan dan pengolahan lebih lanjut atau perlu sentuhan teknologi untuk meningkatkan nilai gizinya, dikarenakan bahan lumpur sawit ini mempunyai beberapa kelemahan yaitu serat kasar tinggi, kandungan protein dan kecernaan rendah (Zamora et al., 1989).

Menurut Sinurat et al. (1998), teknologi untuk meningkatkan mutu bahan pakan adalah dengan fermentasi. Teknik ini sudah dilaporkan dapat meningkatkan nilai gizi lumpur sawit (Sinurat et al., 1998; Pasaribu et al., 1998). Secara umum semua produk akhir fermentasi biasanya mengandung senyawa yang lebih sederhana dan mudah dicerna dari pada bahan asalnya sehingga dapat meningkatkan nilai gizinya (Purwadaria et al., 1999; Sinurat et al., 2000; Supriyati et al., 1998)

Kandungan nutrisi lumpur sawit fermentasi yang difermentasi dengan Neurospora crassa adalah PK 23,45\%, SK $17,34 \%$, energi (ME) $1774 \mathrm{kal} / \mathrm{g}$, Ca 1,32\% dan P 0,56\% (Fenita, 2009). Pemanfaatan LSF masih belum optimal karena LSF mempunyai kandungan asam amino essensial yang masih sangat rendah, terutama kadungan asam amino lisin dan metionin. Walaupun Sinurat et al. (2000), Sinurat (2003) dan Fenita (2007) telah mampu memperbaiki nilai gizi LSF, namun belum memberikan hasil yang maksimal untuk meningkatkan performans produksi. Hal ini diduga karena LSF defisien akan asam amino lisin dan metionin dan tidak seimbangnya asam amino essensial.

Barnes et al. (1995) menyatakan bahwa kualitas protein tergantung dari keseimbangan dan kelengkapan asam amino essensialnya. Asam amino esensial yaitu asam amino yang harus disediakan dalam pakan karena ternak tidak mampu atau hanya sedikit mensintesanya. Yang termasuk asam amino esensial adalah: lisin, methionine, valin, histidin, fenilalanin, arginine, isoleusin, threonin, leusin, dan triptopan. Asam amino lisin, metionin, dan triptopan merupakan asam amino yang perlu diperhatikan di dalam penyusunan ransum karena lisin merupakan asam amino pembatas utama unggas disusul metionin sebagai asam amino pembatas kedua, kemudian triptopan merupakan asam amino essensial dalam pakan unggas (Lesson \& Summers, 2001).

Fenita et al. (2002) telah menguji pemanfaatan ASF (Ampas sagu fermentasi) yang disuplementasi asam amino essensial dapat meningkatkan kualitas telur sehingga memberikan nilai tambah baik untuk kesehatan maupun terhadap harga jual telur yang dihasilkan. Jadi, tuntutan konsumen untuk mendapatkan kualitas telur yang sempurna mungkin dapat dipenuhi dengan cara memodifikasi zat gizi. Modifikasi zat gizi ini adalah melalui suplementasi asam amino essensial dalam ransum berbasis LSF yang kaya 
akan $\beta$ karoten, dengan harapan dapat meningkatkan kualitas telur ayam.

\section{MATERI DAN METODE}

Bahan yang digunakan dalam penelitian ini adalah 40 ekor ayam petelur, serta bahan pakan yang terdiri dari jangung giling, kosentrat, LSF, dedak halus, asam amino lisin, metionin, triptopan, dan mineral mix. Pembuatan lumpur sawit yang sudah kering, ditambahkan aquades (kadar air 70\%) diaduk secara merata, kemudian dikukus selama 30 menit setelah air mendidih untuk mensterilkan bahan, setelah itu dibiarkan sampai tercapai suhu kamar. Substrat kemudian diinokulasi inokulum kapang Neurospora crassa. Diaduk secara merata dan diinkubasi selama 7 hari (5 hari aerob, 2 hari anaerob). Setelah itu produk fermentasi dipanen, dikeringkan dengan menggunakan sinar matahari dan digiling. Rangkaian teknik fermentasi prosesnya disajikan pada gambar 1 .

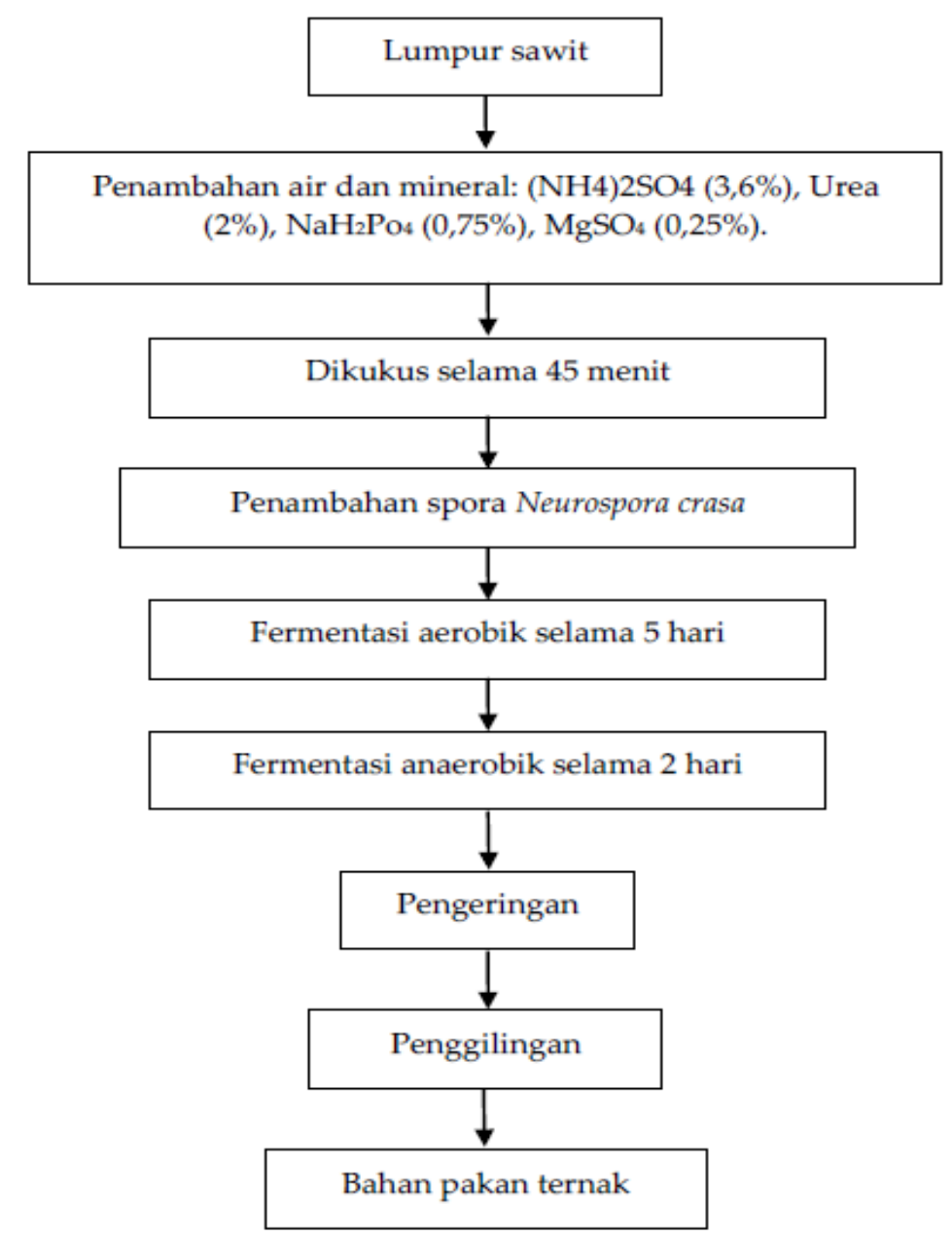

Gambar 1. Alur proses fermentasi Lumpur sawit untuk bahan pakan ternak (Pasaribu et al., 1998) 
Tabel 1. Komposisi dan kandungan nutrien ransum perlakuan

\begin{tabular}{lcccc}
\hline \multirow{2}{*}{ Bahan Pakan } & \multicolumn{4}{c}{ Ransum Perlakuan } \\
\cline { 2 - 5 } & P0 (Kontrol) & $\begin{array}{c}\text { P1 } \\
\text { (50\% AAK) }\end{array}$ & $\begin{array}{c}\text { P1 } \\
\text { (75\% AAK) }\end{array}$ & $\begin{array}{c}\text { P3 } \\
(100 \% \text { AAK) }\end{array}$ \\
\hline Jagung Giling (\%) & 33 & 33 & 33 & 33 \\
Konsentrat (\%) & 30 & 30 & 30 & 30 \\
LSF (\%) & 15 & 15 & 15 & 15 \\
Dedak Halus (\%) & 20 & 20 & 20 & 20 \\
Mineral Mix (\%) & 2 & 2 & 2 & 2 \\
Total (\%) & 100 & 100 & 100 & 100 \\
Protein Kasar (\%) & 17,52 & 17,52 & 17,52 & 17,52 \\
ME (kkal/kg) & 2754,20 & 2754,20 & 2754,20 & 2754,20 \\
Serat Kasar (\%) & 7,03 & 7,03 & 7,03 & 4,03 \\
Kalsium (\%) & 4,0 & 4,0 & 4,0 & 1,54 \\
Phospor (\%) & 1,54 & 1,54 & 1,54 & 6,17 \\
Lemak (\%) & 6,17 & 6,17 & 6,17 & 809 \\
Lisin (mg/hen/day) & 0 & 404,5 & 606,75 & 501 \\
Metionin (mg/hen/day) & 0 & 250,5 & 375,75 & 181 \\
Triptopan (mg/hen/day) & 0 & 90,5 & 135,75 & \\
\hline Keterangan: Rekomendasi Lesson \& Summer (2001), Metionin 501 mg/hen/day, Triptopan 181 mg/hen/day, Lisin & &
\end{tabular}

Ransum yang digunakan adalah ransum P0: Tanpa penambahan asam amino, ransum P1: Ditambah $50 \%$ asam amino (Lys 113,26gr; Met 70,14gr; Trp 36,2gr), ransum P2: Ditambah $75 \%$ asam amino (Lys 169,89gr; Met 105,21gr; Trp 63,35gr), dan ransum P3: Ditambah $100 \%$ asam amino (Lys 226,52gr; Met 140,28gr; Trp 72,4gr), penambahan asam amino ini adalah dalam $100 \mathrm{~kg}$ bahan pakan.

Pelaksanaan penelitian adalah selama 90 hari, setiap perlakuan terdiri dari 10 buah kandang yang berisi 1 ekor ayam petelur (individual cage). Ransum dan air minum diberikan secara ad libitum. Rancangan yang digunakan adalah Rancangan acak lengkap, pada penelitian ini digunakan ayam petelur fase produksi umur 8 bulan sebanyak 40 ekor. Ayam petelur tersebut terbagi dalam 4 perlakuan dengan 10 ulangan dan setiap ulangan berisi 1 ekor ayam.

\section{Variabel yang diamati}

Konsumsi Ransum (gr/hari). Konsumsi ransum dihitung setiap 1 minggu dengan cara jumlah ransum yang disediakan awal minggu, kemudian dikurangi dengan sisa ransum akhir minggu. Konversi Ransum. Konversi ransum diukur dengan cara membandingkan jumlah ransum yang dikonsumsi dengan berat telur yang dihasilkan. Berat Telur Ayam (gr). Berat telur ayam diukur setiap minggu dengan cara menimbang semua jumlah telur hingga didapatkan berat total dibagi dengan jumlah telur yang dihasilkan dalam satu minggu. Produksi Telur (\%): Produksi telur selama penelitian dihitung dengan cara mempersentasekan jumlah telur yang diproduksi perminggu pada setiap perlakuan. Warna Yolk Warna yolk diukur berdasarkan skor warna (1-15) yang pengukuranya menggunakan Roche Yolk Colour Fan dan diukur tiap akhir minggu. Income Over Feed Cost. Income over feed cost didapat dengan cara mengurangkan harga telur yang dihasilkan dengan biaya makanan yang dihabiskan. 
Tabel 2. Kandungan gizi sebelum dan sesudah fermentasi dengan Neurospora crassa

\begin{tabular}{lcc}
\hline Komposisi & Lumpur sawit & Lumpur sawit fermentasi \\
\hline Protein kasar (\%) & 13,57 & 23,45 \\
Serat kasar (\%) & 28,03 & 17,34 \\
Lemak Kasar (\%) & 11,67 & 9,45 \\
Energi Metabolisme (kkal/kg) & $1632 \mathrm{kal} / \mathrm{g}$ & $1774 \mathrm{kal} / \mathrm{g}$ \\
Abu (\%) & 27,34 & 24,43 \\
Ca (\%) & 1,46 & 1,32 \\
P (\%) & 0,37 & 0,56 \\
Beta Karoten $\mu \mathrm{g} / 100 \mathrm{~g}$ & 1873,4 & 3735,6 \\
Metionin (\%) & 0,29 & 0,36 \\
Lisin (\%) & 0,34 & 0,39 \\
\hline
\end{tabular}

Bahan ransum yang digunakan dalam menyusun ransum penelitian disajikan pada Tabel 1.

\section{HASIL DAN PEMBAHASAN}

Teknologi fermentasi dengan mengunakan kapang Neurospora crassa mampu menguraikan serat kasar lumpur sawit yang kompleks menjadi yang sederhana. Pada proses tersebut sumber nitrogen anorganik dapat diubah menjadi protein sel mikroba dan juga menghasilkan enzim hidrolitik yang dapat meningkatkan daya cerna lumpur sawit tersebut. Lumpur sawit dapat digunakan sebagai salah satu bahan pakan unggas setelah difermentasi dengan Neurospora sp, hal tersebut disebabkan setelah difermentasi kandungan protein kasar lumpur sawit akan meningkat dari $13,57 \%$ menjadi 23,45\% (Fenita, 2009). Kandungan gizi lumpur sawit yang sebelum dan sesudah difermentasi dapat dilihat pada tabel 2.

Berdasarkan hasil analisis terjadi peningkatan total asam amino dari 7,02\% menjadi 8,54\% (Fenita et al., 2009). Kandungan $\beta$-karoten produk fermentasi memberikan peningkatan yang sangat berarti untuk peningkatan nilai $\beta$ karoten, dimana peningkatannya mencapai hampir dua kali lipat yaitu sebesar $1860 \mu \mathrm{g} / 100 \mathrm{~g}$ pada produk fermentasi dengan Neurospora sp, dimana yang sebelum difermentasi hanya sebesar $1873,4 \mu \mathrm{g} / 100 \mathrm{~g}$ dan yang sudah difermentasi mencapai 3735,8 $\mu \mathrm{g} / 100 \mathrm{~g}$. Hasil kandungan $\beta$ karoten pada produk lumpur sawit fermentasi (LSF) ini memiliki kandungan karoten yang lebih tinggi dari yang diteliti oleh Nuraini (2006), dimana kandungan karoten dari fermentasi Neurospora sp yang menggunakan campuran $60 \%$ ampas sagu dengan $40 \%$ ampas tahu hanya sebesar $2700,60 \mu \mathrm{g} / 100 \mathrm{~g}$. 
Table 3. Rataan Konsumsi Ransum (gr/hari/ekor), Konversi Ransum, produksi Telur (\%), Berat telur (g), Indeks Warna Yolk dan Income over feed Cost (Rp) dengan penambahan asam amino lisin, metionin dan tritopan dalam ransum berbasis lumpur sawit fermentasi (LSF).

\begin{tabular}{lrrrr}
\hline \multirow{2}{*}{ Minggu } & \multicolumn{4}{c}{ Perlakuan } \\
\cline { 2 - 5 } & \multicolumn{1}{c}{ P0 } & \multicolumn{1}{c}{ P1 } & \multicolumn{1}{c}{ P2 } \\
\hline Konsumsi ransum (gr/hari/ekor) & $128,84 \pm 2,45$ & $128,48 \pm 1,85$ & $128,63 \pm 1,38$ & $128,46 \pm 2,17$ \\
Konversi ransum & $2,54 \pm 0,08$ & $2,46 \pm 0,11$ & $2,51 \pm 0,14$ & $2,55 \pm 0,09$ \\
Produksi Telur (\%) & $79,46 \pm 2,53$ & $80,42 \pm 3,21$ & $80,13 \pm 3,27$ & $79,04 \pm 2,51$ \\
Berat Telur (g) & $64,01 \pm 0,12$ & $65,13 \pm 0,59$ & $64,12 \pm 0,71$ & $63,82 \pm 0,32$ \\
Warna Yolk & $7,78^{\mathrm{a}}$ & $8,56^{\mathrm{b}}$ & $8,22^{\mathrm{b}}$ & $8,19^{\mathrm{b}}$ \\
lncome over feed cost (Rp) & $197.076,26$ & $182.957,40$ & $158.563,91$ & $131.919,92$ \\
\hline
\end{tabular}

Keterangan: Superskrip yang berbeda pada baris yang sama menunjukkan berbeda nyata $(\mathrm{P}<0,05)$

\section{Konsumsi Ransum}

Pengaruh pemberian asam amino essensial (lisin, metionin dan tritopan) sebanyak $50 \%$, $75 \%$ dan $100 \%$ dari yang direkomendasikan oleh Lesson \& Summers (2001) dalam ransum berbasis lumpur sawit fermentasi sebanyak 15\% terhadap konsumsi ayam petelur disajikan pada Tabel 3.

Konsumsi ransum rata-rata pada penelitian ini berkisar 128,46 sampai 128,84 gr/ekor/hari, dan berdasarkan hasil analisis sidik ragam ternyata tidak berbeda nyata $(\mathrm{P}>0,05)$ pada masingmasing perlakuan. Pada penelitian tahap 1 penggunaan lumpur sawit fermentasi dengan level yang berbeda memberikan pengaruh yang nyata terhadap konsumsi, ayam lebih banyak mengkonsumsi pakan yang mengandung LSF dikarenakan LSF bersifat bulky sehingga untuk mencukupi kebutuhan protein dan energinya akan mengkonsumsi lebih banyak (Fenita, 2009). Selain itu pada fermentasi terjadi proses - proses pemecahan oleh enzim - enzim tertentu terhadap zat -zat makanan yang sulit dicerna, sehingga daya cerna bahan yang telah difermentasi meningkat dibandingkan bahan asal (Murugesan et al., 2005). Pada penelitian ini penambahan asam amino ternyata tidak memberikan pengaruh yang nyata terhadap konsumsi sehingga akan lebih baik dan efisien bila ransum berbasis lumpur sawit ini tidak disuplementasi asam amino esensial. Pemberian asam amino pada penelitian ini tidak memberikan pengaruh nyata karena faktor utama yang mempengaruhi tingkat konsumsi ransum adalah kandungan energi ransum dan juga suhu lingkungan seperti yang telah dijabarkan pada bab sebelumnya. Energi ransum pada penelitian ini diberikan sama tiap perlakuannya sehingga hasil menunjukkan perlakuan tidak berbeda nyata terhadap konsumsi ransum.

Konversi ransum ini dihitung berdasarkan jumlah pakan yang dikonsumsi di bagi dengan jumlah telur yang dihasilkan. Hasil penelitian menunjukkan bahwa pemberian suplementasi asam amino kritis tidak berpengaruh nyata terhadap konversi ransum $(P>0,05)$. Bahkan nilai $F C R$ P0 dan P4 hampir sama. Walaupun hasil pengamatan menunjukkan tidak ada perbedaan yang nyata namun pada perlakuan P1 yaitu pemberian suplementasi asam amino essensial 50\% memberikan hasil konversi ransum yang paling baik yaitu 2,46 artinya untuk 
menghasilkan $1 \mathrm{~kg}$ telur membutuhkan $2,46 \mathrm{~kg}$ pakan.

Berdasarkan hasil analisis sidik ragam perlakuan tidak berpengaruh nyata terhadap produksi telur $(P>0,05)$. Hal ini dikarenakan ransum yang diberikan adalah ransum iso-kalori $(2.754,20 \mathrm{kkal} / \mathrm{kg}$ energi metabolis) dan iso-protein $(17,52 \%)$, dengan tingkat konsumsi ransum sama antar perlakuan, sehingga asupan energi maupun protein pada semua ayam juga sama. Pemberian asam amino $100 \%$ dari yang direkomendasikan, memberikan dampak penurunan berat badan pada ayam broiler (Fenita, 2002 ; Fenita et al., 2009). Menurut North dan Bell (1990), rataan produksi ayam petelur tipe medium pada minggu produksi 32-40 adalah $80,55 \%$. Faktor yang mempengaruhi produksi adalah jenis dan bangsa, umur ayam, suhu lingkungan, dan juga nutrisi ransum yang digunakan. Pada Penelitian ini yang berbeda adalah kandungan asam amino dalam ransum, dengan penambahan asam amino diharapkan dapat meningkatkan produksi dan hasil menunjukkan perlakuan tidak berbeda nyata sehingga dapat disimpulkan ransum dengan imbangan protein $18,52 \%$ dan energi $2754,20 \mathrm{kkal} / \mathrm{kg}$ tidak perlu disuplementasi asam amino essensial.

Hasil penelitian menunjukkan bahwa suplementasi asam amino essensial tidak berpengaruh nyata terhadap berat telur $(P>0,05)$. Bila dibandingkan dengan kontrol, perlakuan P1 dan P2 dengan suplementasi asam amino essensial cenderung meningkatkan meningkatkan bobot telur, meskipun peningkatan ini tidak berbeda secara statistik $(P>0,05)$. Metionin merupakan asam amino esensial kritis yang sangat berpengaruh terhadap bobot telur (Safaa et al., 2008 dan Keshavarz, 2003). Juga menurut Lesson \& Summer (2001) asam amino metionin lebih superior dibandingkan dengan sumber asam amino yang lain dalam peningkatan bobot telur, karena asam amino sintetik dalam bentuk campuran DL-metionin pemanfaatannya dalam bentuk isomer bisa mencapai $100 \%$, metionin berperan sebagai pendonor metil, sehingga berperan dalam membantu metabolisme yang lain dalam tubuh seperti metabolisme kholin, protein dan karbohidrat.

Pengamatan warna yolk dilakukan pada setiap akhir minggu. Hasil penelitian menunjukkan bahwa suplementasi asam amino essensial dalam ransum berbasis LSF berpengaruh nyata terhadap kecerahan warna yolk. Warna Yolk yang paling cerah adalah pada P1 yaitu 8,56. Penggunaan LSF sebesar $20 \%$ dalam ransum bisa meningkatkan warna yolk dengan skore 9,88 (Fenita et al., 2009)). Nilai ini berada dalam kisaran warna kuning telur yang disukai konsumen menurut Udedibie and Opara (1998) yaitu 9-12. Sedangkan pada penelitian ini hanya berkisar 7,78 sampai 8,56. Jadi meskipun secara statistik sangat berbeda nyata $(P<0,01)$ akan lebih baik bila ransum berbasis lumpur sawit ini tidak ditambah dengan asam amino essensial. Menurut Hausman dan Sandman (2000) bahwa $\beta$ karoten merupakan senyawa golongan karotenoid yang tidak stabil karena mudah teroksidasi menjadi xantophyl. Xanthophyl tidak bisa disintesis oleh tubuh ayam, oleh karena itu xanthophyl diperoleh dari ransum yang terdiri dari bahan pakan yang mengandung 
xanthopyl (Nuraini et al., 2006). Bahan pakan dalam ransum yang mengandung xanthopyl pada penelitian ini adalah jagung namun penggunaan jagung pada tiap perlakuan adalah sama sedangkan hasil statistik menunjukkan perlakuan berbeda nyata sehingga dalam hal ini yang mempengaruhi peningkatan warna yolk adalah dengan penambahan asam amino. Walaupun ayam mengkonsumsi ransum secara proporsional relatif sama, suplementasi triptopan dalam ransum (Tabel 2) juga ditingkatkan sehingga asupan dan penyerapan triptopan akan meningkat, yang diduga menyebabkan terjadinya perubahan warna kuning telur yang semakin pekat. Pernyataan ini didukung oleh Wahju (1992), bahwa ketersediaan triptopan yang berlebih dalam ransum akan memberi dampak pada peningkatan warna kuning telur.

Rataan income over feed cost pada masing-masing perlakuan selama penelitian sampai dengan akhir penelitian income over feed cost tertinggi diperoleh pada P0 yaitu pada perlakuan tanpa penambahan asam amino essensial.

\section{SIMPULAN}

Hasil penelitian dapat disimpulkan bahwa pemberian suplementasi asam amino essensial dalam ransum berbasis lumpur sawit tidak berpengaruh nyata terhadap performans produksi ayam petelur. Sedangkan untuk kecerahan warna yolk memberikan pengaruh yang nyata, Income over feed cost yang tertinggi pada P0 yaitu perlakuan tanpa pemberian asam amino essensial selama penelitian (Rp 197.076,26).

\section{DAFTAR PUSTAKA}

Barnes, D.M. C.C. Calvert and K.C.Klasing. 1995. Methionin defeciences protein and sistim but not rna acylation in muscles of chick. J. Nutr. 125 : 2623-2630.

Bell, D.D. and D.W.Jr. William. 2001. Commercial Chicken Meat and Egg Production. Kluwer Academi. Publisher. Mashachuset. USA.

Fenita, Y. 2002. Suplementasi lisin dan metionin serta minyak lemuru ke dalam ransum berbasis hidrolisat bulu ayam terhadap perlemakan dan pertumbuhan ayam ras pedaging. Program Pasca SarjanaIPB, Bogor.

Fenita, Y., D. Kaharudddin, H. Prakoso. 2007. Pemanfaatan ampas sagu fermentasi (Metrilon sp) dalam ransum berbasis minyak ikan lemuru (Sardinella longiceps) terhadap kualitas telur ayam petelur. Laporan Penelitian PHK A2 Jurusan Peternakan Unib.

Fenita, Y., U. Santoso, H. Prakoso. 2009. Performans dan kualitas kuning telur ayam yang menggunakan ransum mengandung lumpur sawit fermentasi dengan neurospora crassa. Laporan Penelitian HPSN Batch II tahun 2009. Unib Bengkulu.

Hausmann, A. and G. Sandmann. 2000. A single five-step desaturase is involved in the carotenoid 
biosynthesis pathway to betacarotene and torulene in neurospora crassa. J. Genet. Biol. 30(2): 147-53.

Keshavarz, K. 2003. Effects of reducing dietary protein, methionine, choline, folic acid, and vitamin b12 during the late stages of the egg production cycle on performance and eggshell quality. Poult. Sci. 82:1407-1414.

Lesson, S. and J.D. Summers. 2001. Nutrition of The Chicken. 4 th ed. United Books. Guelp, Ontario, Canada.

Murugesan, G.S., M. Sathishkumar, K. Swarninathan. 2005. Suplementation of waste tea fungal biomass as a dietary ingredien for Broiler chicken. Bioresource Technology 96: 17431748.

Nuraini. 2006. Potensi kapang Neuraspora crassa dalam memproduksi pakan kaya karoten dan pengaruhnya terhadap ayam pedaging dan petelur. Disertasi. Program Pascasarjana Universitas Andalas, Padang.

Nuraini, Sabrina dan S.A. Latif. 2007. Potensi Neuraspora crassa dalam meningkatkan kualitas onggok menjadi pakan kaya b karoten. Laporan Hibah Bersaing Tahap I Dikti. Lembaga Penelitian Univ. Andalas, Padang.

Pasaribu, T., A.P. Sinurat, T. Purwadana, Supriyati dan H. Hamid. 1998. Peningkatan nilai gizi lumpur sawit melalui proses fermentasi. pengaruh jenis kapang, suhu dan lama proses enzimalis. J. Ilmu Ternak Vet. 3(4); 237-242.

Purwadaria, T., A.P. Sinurat, Supriyati, H. Hamid, dan I.A.K. Bintang. 1999. Evaluasi nilai gizi lumpur sawit fermentasi dengan aspergillus niger setelah proses pengeringan dengan pemanasan. J. Ilmu Ternak Vet. 4 (4) : 257263).

Safaa, H.M., D.G. Valencia, X Arbe, E Jiménez-Moreno, R. Lázaro, G.G Mateos G.G. 2008. Effects of the levels of methionine, linoleic acid, and added fat in the diet on productive performance and egg quality of brown laying hens in the late phase of production. Poult. Sci. 87(8):1595-602.

Sinurat, A.P. 1998. Pengaruh suhu ruang fermentasi dan kadar air substrat terhadap nilai gizi produk fermentasi lumpur sawit. J. Ilmu Ternak Vet. 3(4): 225-229)

Sinurat, A.P., T. Purwadaria, H. Surachaman, H. Hamid dan I.P. Kompiang. 1998. Pengaruh suhu ruangan fermentasi dan kadar air substrat terhadap nilai gizi produk fermentasi lumpur sawit. J. Ilmu Ternak Vet. 3: 225-279.

Sinurat, A.P., T. Purwadaria, P. Ketaren, D. Zainuddin dan I.P. Kompiang. 2000. Pemanfaatan Lumpur Sawit Untuk Ransum Unggas: 1. Lumpur Sawit Kering dan Produk Fermentasinya Sebagai Bahan Pakan Ayam Broiler. J. Ilmu Ternak Vet. 5(2): 107-112.

Sinurat, A.P. 2003. Pemanfaatan Lumpur Sawit untuk Bahan Pakan 
Unggas. Wartoza. Buletin Ilmu Peternakan Indonesia 13(2)39-47.

Udedibie, A.B.I. \& C.C. Opara. 1998. Responses of growing of Broiler and Laying hens to the dietary inclusion of leaf meal from Alchornia cordifilia. Animal Feed Sci. and Tech. 71: 157-164.

Yeong, S.W. 1982., The Nutrinue Value of Palm Oil by Product For Poultry, In : Anim Prod. and Health in The Tropics. M.R. Jainudeen and A.R. Omar (Eds). University Pertanian Malaysia, Selangor: 217-222.
Wahju. J. 1992. Nutrisi Ternak Unggas. Gramedia, Jakarta.

Zamora, A.F., M.R. Caloparda, K.P. Rosano, E.S. Luis, and I.F. Dalmacio. 1989. Improvement of copra meal quality for use in animal feeds. Proc. F AP/UNDP Workshop on Biotechnology in Animal Production and Health in Asia and Latin America pp. 312320. 